\title{
JOB TENURE AND CYCLICAL CHANGES IN THE LABOR MARKET*
}

By: Christopher J. Ruhm

Ruhm, Christopher J. "Job Tenure and Cyclical Changes in the Labor Market", Review of Economics and Statistics, Vol. 69, No. 2, May, 1987, 372-78.

Made available courtesy of Massachusetts Institute of Technology Press: http://www.mitpressjournals.org/loi/rest?cookieSet=1

****Note: Figures may be missing from this format of the document

\begin{abstract}
:
Using data on male heads of households from the Michigan Panel Study of Income Dynamics, this paper finds that although short tenure workers accounted for a disproportionate share of total unemployment, during the early seventies, cyclical fluctuations in joblessness were concentrated among persons currently holding or recently having held longer-lasting employment. Greater unemployment durations were a more important source of rising joblessness than increased separation probabilities and cyclical changes in both variables were larger for recent leavers of medium or long tenure employment than for persons with similar seniority in their current job.
\end{abstract}

\section{Article:}

I. Introduction

Economists have long been interested in the distribution of cyclical changes in employment and unemployment. For example, Clark and Summers (1981) argue that employment fluctuations are disproportionately concentrated among teenagers and young women and that, contrary to some earlier studies (e.g., Feldstein (1973)), these groups receive substantial benefits from policies which increase aggregate demand. ${ }^{1}$ Despite the important role of job seniority in most theories, limited empirical evidence has been obtained on tenure group variations in cyclical labor market flows. ${ }^{2}$

This paper provides information on two related questions. Section II examines how cyclical fluctuations in unemployment, among male heads of households, are distributed across workers with different employment durations. Section III decomposes the total effect into changes in job separation probabilities as compared to post-separation reductions in employment and evaluates the relative importance of each.

Throughout the paper, I emphasize the distinction between seniority in the current job and tenure in the longest recently held position. While the former mea- sure of job duration is most important for theories emphasizing firm specific skills or institutional arrangements, tenure in

\footnotetext{
* I would like to thank George Akerlof, Lloyd Ulman, Robert Solow, Lawrence Summers, Peter Doeringer, Thomas McGuire and two anonymous referees for helpful comments on earlier versions of this paper. I would also like to thank my parents for their trust and confidence.

${ }^{1}$ For instance, teenagers and twenty to thirty-four year old females compose $9.2 \%$ and $15.5 \%$ of the population but $26.7 \%$ and $23.8 \%$ of cyclical employment fluctuations (Clark and Summers, 1981, p. 69).

${ }^{2}$ See Raisian (1983) and Darby et al. (1985) for research which does consider seniority.
} 
recent previous jobs provides information on unobserved worker characteristics and labor force attachment (for further discussion, see Ruhm (1986)).

Information on prior job duration is especially important for evaluating several currently popular macro- economic explanations of employment fluctuations. For example, equilibrium business cycle models (Lucas and Rapping, 1969; MaCurdy, 1981) emphasize the importance of labor supply responses to transitory wage changes and predict that employment variations should be concentrated among groups with high reservation wages. To the extent that reservation wages change in predictable ways over the lifetime, these will be workers with weak labor force attachments and histories of short employment tenures. Similarly, recent dual labor market theories argue that secondary labor markets serve as a buffer protecting the primary sector from fluctuations in aggregate demand (see Piore (1979)). Secondary workers then have low average job tenures because of their vulnerability to cyclical slowdowns in the economy. In both models, cyclical employment changes will be concentrated among workers with short tenure in current and recently held jobs. Section II presents evidence that, at least for prime-age males, this is not the case. Although disproportionate shares of cyclical changes in unemployment fall upon persons with "short" (less than three years) current tenure, a substantial share of the employment change is accounted for by workers with more than three years seniority in recently held previous jobs.

Consistent with earlier research (Hall, 1972; Marston, 1976), section III shows that turnover probabilities de- cline rapidly with tenure and that cyclical employment fluctuations result more from changes in unemployment durations than in separation probabilities. The analysis does reveal two surprises. First, there is no statistically significant cyclical change in either separation probabilities or post-separation employment reductions for per- sons with less than three years seniority. Second, high tenure workers find new jobs as fast or faster than their low seniority counterparts, in contrast to predictions of simple search models stressing the relationship between tenure and reservation wages.

\section{Labor Market Flows: Preliminary Evidence}

Analysis of labor market flows became popular in the early seventies to explain variations in unemployment rates across demographic groups. Early work (Hall, 1972; Feldstein, 1973) emphasized differences in turnover probabilities, while later research showed that short unemployment durations among high turnover groups result more from large propensities to leave the labor force, when unemployed, than from rapid reemployment (Marston, 1976; Akerlof and Main, 1980) and also that "long" unemployment spells account for the bulk of total weeks of unemployment, despite short average spell lengths (Clark and Summers, 1979).

Separation rates decline with job tenure, due to acquisitions of firm specific human capital, seniority based layoff policies, and better employer — employee job "matches." We know less about the relationship between tenure and either post-separation unemployment durations or cyclical variations in transition probabilities, and economic theory gives few clear predictions in these areas. For example, increased seniority might be associated with longer unemployment spells, if tenure increases earnings and consequently reservation wages, or shorter joblessness if high tenure persons are more averse to spells of nonemployment. 
To shed light on these questions, I use data on three calendar years from the Panel Study of Income Dynamics (PSID). The sample in this section includes male head of households aged twenty-five to sixty-five, during the survey year, who participated in the labor force during some part of that year and the two preceding it and contains approximately three thousand usable observations per year. ${ }^{3}$ To obtain cyclical patterns, I com- pare the two recession years 1971 and 1975 to the 1973 business cycle peak. ${ }^{4}$ Workers are grouped as having "short" (less than three years), "medium" (three to nine years), or "long" (ten or more years) tenure in their current or most recent pre-separation employment and also in the longest job held during the previous three years. ${ }^{5}$

Table 1 categorizes workers by seniority and various measures of unemployment Columns 2 and 3 show the familiar result that unemployment becomes less probable as seniority increases. For instance, holders of "short" jobs are 4.7 times more likely to experience unemployment than those with more than ten years seniority and almost 8 times as probable to be unemployed over half the year. Changing jobs within the previous two years (rows 7 through 9) increase unemployment probabilities, but unemployment still falls

\begin{tabular}{|c|c|c|c|c|c|c|c|}
\hline \multirow[b]{3}{*}{$\begin{array}{l}\text { Tenure } \\
\text { (Years) }\end{array}$} & \multirow[b]{3}{*}{$\begin{array}{l}\text { Population } \\
\text { Share (\%) }\end{array}$} & \multirow{2}{*}{\multicolumn{2}{|c|}{$\begin{array}{c}\text { Probability of } \\
\text { Unemployment (\%) }\end{array}$}} & \multicolumn{4}{|c|}{ Share of Change in Unemployment (\%) } \\
\hline & & & & \multicolumn{2}{|c|}{1971 to 1973} & \multicolumn{2}{|c|}{1973 to 1975} \\
\hline & & $\begin{array}{c}>1 \\
\text { week }\end{array}$ & $\begin{array}{c}>26 \\
\text { weeks }\end{array}$ & $\begin{array}{c}>1 \\
\text { week }\end{array}$ & $\begin{array}{c}>26 \\
\text { weeks }\end{array}$ & $\begin{array}{c}>1 \\
\text { week }\end{array}$ & $\begin{array}{c}>26 \\
\text { weeks }\end{array}$ \\
\hline \multicolumn{8}{|c|}{ Current Job-Full Sample $(n=9820)$} \\
\hline$<3$ & $18.7 \%$ & $\begin{array}{l}23.0 \% \\
(1.0 \%)\end{array}$ & $\begin{array}{l}3.8 \% \\
(0.5 \%)\end{array}$ & $27.0 \%$ & $60.0 \%$ & $34.9 \%$ & $31.3 \%$ \\
\hline $3-9$ & 39.0 & $\begin{array}{l}11.6 \\
(0.5)\end{array}$ & $\begin{array}{l}1.1 \\
(0.2)\end{array}$ & 25.0 & 26.7 & 36.6 & 37.5 \\
\hline$\geq 10$ & 42.3 & $\begin{array}{l}4.9 \\
(0.4)\end{array}$ & $\begin{array}{c}0.5 \\
(0.1)\end{array}$ & 55.1 & 13.3 & 28.4 & 31.3 \\
\hline \multicolumn{8}{|c|}{ Longest Job-Full Sample $(n=9820)$} \\
\hline$<3$ & 6.9 & $\begin{array}{l}29.4 \\
(1.8)\end{array}$ & $\begin{array}{c}6.1 \\
(0.4)\end{array}$ & -3.6 & 0.0 & 16.0 & 14.7 \\
\hline $3-9$ & 45.6 & $\begin{array}{l}13.5 \\
(0.5)\end{array}$ & $\begin{array}{c}1.5 \\
(0.2)\end{array}$ & 31.9 & 42.9 & 56.7 & 55.9 \\
\hline$\geq 10$ & 47.5 & $\begin{array}{c}7.9 \\
(0.4)\end{array}$ & $\begin{array}{c}0.6 \\
(0.1)\end{array}$ & 71.7 & 57.1 & 27.3 & 29.4 \\
\hline \multicolumn{8}{|c|}{ Previous Job-Recent Job Changers $(n=2030)$} \\
\hline$<3$ & 6.2 & $\begin{array}{l}31 . \overline{0} \\
(1.9)\end{array}$ & $\begin{array}{l}6.7 \\
(1.0)\end{array}$ & -5.1 & 0.0 & 15.0 & 14.7 \\
\hline $3-9$ & 11.0 & $\begin{array}{l}25.1 \\
(1.3)\end{array}$ & $\begin{array}{l}5.0 \\
(0.7)\end{array}$ & 11.6 & 0.0 & 20.3 & 44.1 \\
\hline \multirow[t]{2}{*}{$\geq 10$} & 3.4 & $\begin{array}{l}21.1 \\
(2.2)\end{array}$ & $\begin{array}{l}2.6 \\
(0.9)\end{array}$ & 18.8 & 42.9 & 13.4 & 8.8 \\
\hline & (1) & (2) & (3) & (4) & (5) & (6) & (7) \\
\hline
\end{tabular}

Source: PSID 1969-1975.

Note: Percent standard errors in parentheses.

\footnotetext{
${ }^{3}$ Ideally, females and non-household heads would also be studied. Unfortunately, data limitations in the PSID prevent analysis of these groups.

${ }^{4}$ The aggregate unemployment rate was $5.9 \%$ in $1971,4.9 \%$ in 1973, and $8.5 \%$ in 1975 ; the corresponding sample unemployment rates were $3.13 \%, 1.82 \%$, and $3.46 \%$.

${ }^{5}$ Calculating job tenure is complicated because the PSID reports seniority only for individuals employed at the time of the survey. If a worker changed jobs during the previous year, it was therefore necessary to go back one and sometimes two survey periods to obtain the relevant tenure information.
} 
with previous job duration. For example, holders of prior "long" jobs are a third less likely to become unemployed and almost two-thirds less probable to be unemployed over twenty-six weeks than workers with "short" previous employment.

Columns 4 through 7 present information on changes in unemployment between the 1973 business cycle peak and the two adjacent recessions. Considering current seniority first (rows 1 through 3), short tenure workers are responsible for a disproportionate share of cyclical employment fluctuations, accounting for under a fifth of the population but $27 \%$ to $35 \%$ of the cyclical increases in unemployment and between $31 \%$ and $60 \%$ of cyclical changes in "long" (over twenty-six weeks) unemployment. Conversely, the percentages for medium and long tenure workers are usually smaller than their population shares.

Comparing rows 1 to 3 of table 1 to the six subsequent rows illustrates that exclusive focus on current seniority can be misleading. Individuals whose longest recent job tenure is less than three years (row 4) account for none of the unemployment change occurring between 1971 and 1973 and a fairly small percentage of that between 1973 and 1975. Conversely, long tenure recent job holders (row 6) experienced particularly large reductions in unemployment as the economy recovered in the early seventies and the medium tenure group (row 5) the greatest increases during the post-1973 economic deterioration.

The different cyclical patterns for current versus longest recent job tenure, suggest special focus on workers who have changed jobs in the two years prior to the base period. These are defined as recent job changers and considered in rows 7 through 9 of table 1 . We have already discussed the high unemployment probabilities for this group. Columns 4 through 7 show that recent leavers of "long" jobs are also responsible for large shares of cyclical fluctuations in unemployment. Although constituting only $3.4 \%$ of the population, they account for between $13 \%$ and $19 \%$ of the cyclical increases in unemployment experiences and between $9 \%$ and $43 \%$ of changes in "long" unemployment. ${ }^{6}$ Thus leavers of long jobs appear especially vulnerable to further separations and post-separation unemployment if economic conditions subsequently deteriorate.

\section{Transition Probabilities and Tenure}

This section uses a pooled sample for the years 1971 through 1975 to examine how cyclical employment variations are divided between changes in separation probabilities and in postseparation employment reductions. ${ }^{7}$ Included are male heads of households, between the ages of twenty-five and sixty (in 1969), who participated in the labor force during some part of every year between 1969 and $1975 .{ }^{\circ}$ As above, I also separately consider persons changing jobs in the two years prior to the base year (hereafter referred to as "recent job changers"). The tenure variable for recent changers is seniority in the longest job held during the preceding three years, while for the full sample it is duration in the most recent preseparation job. Control

\footnotetext{
${ }^{6}$ In part, this could occur because short tenure job leavers are more likely to exit the labor force and so never be counted as unemployed. To prevent this possibility, the regression analysis of section III uses employment rather than unemployment as the dependent variable.

${ }^{7}$ Since information on jobs held during the two years preceding the base year is utilized, data are actually obtained from 1969 on.

${ }^{8}$ Workers excluded because of non-participation in some survey year probably have relatively short job tenures. Biases from this exclusion will be minimized by the stability of the adult male labor force. For instance, over $87 \%$ of male house-hold heads in the labor force at any time between $1 \% 9$ and 1975 participate in all seven years.
} 
characteristics include experience, experience squared, education, education squared and dummy variables for job tenure, city size, marital status, and race.

Tenure is available only as a categorical variable in the early years of the PSID, requiring the use of dummy variables for short, medium, and long tenure, corresponding to the definitions of the previous section. Data for actual work experience are available in 1974, al- lowing experience to be calculated as 1974 experience plus the difference between the current year and 1974. Most of the other variables are fairly standard. Separations are defined as temporary if the individual returns to the old job within two years and permanent (voluntary or involuntary) otherwise. Weeks worked and reasons for changing jobs are self-reported by the survey recipient.

To ascertain how job termination effects vary with seniority, I interacted the three separation and three tenure variables. Cyclical fluctuations were considered by interacting the various separation and tenure variables with the survey year unemployment rate. ${ }^{9}$

\section{A. Separation Probabilities}

Information on the relationship between separation probabilities and economic conditions was obtained from logit regressions of

$$
S E P_{t}=a X_{t}+b U T E N_{t}+e_{t},
$$

where SEP is a dichotomous variable taking the value one if the requisite type of separation occurs in year $\mathrm{t}, \mathrm{X}$ the control vector of individual characteristics (including tenure), UTEN a vector interacting the unemployment rate with the three tenure categories, and e the error term. Coefficients on UTEN will be positive if worsening economic conditions increase separation probabilities.

Table 2 presents the average and cyclical changes in separation probabilities, obtained from estimates of equation (1), with independent variables other than tenure evaluated at their sample means. ${ }^{10}$ Columns 1,3 , and 5 show average separation probabilities for each tenure group and confirm the standard result that turnover declines with tenure, especially in the first few years of the job. We also observe significant seniority related reductions in permanent separations among re- cent job changers, with corresponding increases for temporary separations.

Columns 2, 4 and 6 show the impact of a one percentage point increase in unemployment above the sample average rate. In the full sample, economic conditions generally have weak effects on separation probabilities, with the only statistically significant results occurring for temporary separations among medium and long tenure workers and involuntary layoffs in the middle group. In contrast, increased unemployment often raises the turnover rates of recent job changers, particularly where the previous job lasted three or more years. For example, worsening economic conditions substantially raise probabilities of permanent separations in the middle tenure

\footnotetext{
${ }^{9}$ To test for potential specification bias in the pooled data, I ran unconstrained versions of the regressions below, where the individual control characteristics have different slopes in each of the five base years and separate year intercepts. The estimated coefficients for tenure, separations, unemployment, and the interactions were virtually unchanged and so results of these regressions are not reported.

${ }^{10}$ Full results of all regressions are available upon request.
} 
category and temporary separations among the longest group. Conversely, we observe no statistically significant cyclical changes in the separation probabilities of workers with short previous jobs.

\section{B. Post-Separation Changes in Employment}

Separations are frequently followed by a spell of joblessness. To see how such employment reductions depend upon tenure and economic conditions, I estimated

$$
E M P_{t}=a X_{t}+b T E N S E P_{t}+c U S E P_{t}+e_{t}
$$

where $\mathrm{X}$ is the vector of control variables, TENSEP a vector of interactions between tenure and the three types of job separations and USEP a vector interacting the unemployment rate with each element in TENSEP. The dependent variable EMP measures weeks of

\begin{tabular}{|c|c|c|c|c|c|c|}
\hline \multirow{3}{*}{$\begin{array}{l}\text { Tenure } \\
\text { (years) }\end{array}$} & \multicolumn{6}{|c|}{ Type of Separation } \\
\hline & \multicolumn{2}{|c|}{ Temporary } & \multicolumn{2}{|c|}{ Involuntary } & \multicolumn{2}{|c|}{ Voluntary } \\
\hline & $A V E$ & $\overline{U R A T E}$ & $A V E$ & $\widehat{U R A T E}$ & AVE & URATE \\
\hline \multicolumn{7}{|c|}{ All Workers (Current Tenure) } \\
\hline$<3$ & $\begin{array}{l}6.93 \% \\
(9.76)\end{array}$ & $\begin{array}{l}1.36 \% \\
(1.47)\end{array}$ & $\begin{array}{l}10.26 \% \\
(1.14)\end{array}$ & $\begin{array}{l}1.96 \% \\
(1.68)\end{array}$ & $\begin{array}{c}14.48 \% \\
(18.10)\end{array}$ & $\begin{array}{l}-0.05 \% \\
(-0.03)\end{array}$ \\
\hline $3-9$ & $\begin{array}{c}5.23 \\
(13.08)\end{array}$ & $\begin{array}{l}1.90 \\
(3.58)\end{array}$ & $\begin{array}{c}3.28 \\
(8.63)\end{array}$ & $\begin{array}{c}1.48 \\
(3.32)\end{array}$ & $\begin{array}{c}6.06 \\
(20.02)\end{array}$ & $\begin{array}{c}0.36 \\
(0.62)\end{array}$ \\
\hline$\geq 10$ & $\begin{array}{c}4.48 \\
(13.58)\end{array}$ & $\begin{array}{c}1.83 \\
(4.19)\end{array}$ & $\begin{array}{c}1.15 \\
(5.00)\end{array}$ & $\begin{array}{c}0.33 \\
(1.40)\end{array}$ & $\begin{array}{c}2.70 \\
(16.88)\end{array}$ & $\begin{array}{l}4.0 \mathrm{E}-3 \\
(0.01)\end{array}$ \\
\hline \multicolumn{7}{|c|}{ Recent Changers (Prior Tenure) } \\
\hline$<3$ & $\begin{array}{c}6.72 \\
(5.60)\end{array}$ & $\begin{array}{c}-0.82 \\
(-0.48)\end{array}$ & $\begin{array}{l}15.73 \\
(7.87)\end{array}$ & $\begin{array}{c}2.39 \\
(0.89)\end{array}$ & $\begin{array}{c}21.46 \\
(12.06)\end{array}$ & $\begin{array}{c}-4.59 \\
(-1.55)\end{array}$ \\
\hline $3-9$ & $\begin{array}{l}10.13 \\
(9.74)\end{array}$ & $\begin{array}{c}1.70 \\
(1.08)\end{array}$ & $\begin{array}{c}9.61 \\
(8.98)\end{array}$ & $\begin{array}{c}6.06 \\
(3.73)\end{array}$ & $\begin{array}{c}11.05 \\
(10.33)\end{array}$ & $\begin{array}{c}4.19 \\
(3.01)\end{array}$ \\
\hline$\geq 10$ & $\begin{array}{c}11.32 \\
(6.58) \\
(1)\end{array}$ & $\begin{array}{c}4.28 \\
(1.64) \\
(2)\end{array}$ & $\begin{array}{c}4.62 \\
(3.06) \\
(3)\end{array}$ & $\begin{array}{c}2.29 \\
(1.34) \\
(4)\end{array}$ & $\begin{array}{c}8.48 \\
(7.19) \\
(5)\end{array}$ & $\begin{array}{c}0.23 \\
(0.11) \\
(6)\end{array}$ \\
\hline
\end{tabular}

calendar year employment. ${ }^{11}$ Results of the regressions are summarized in table 3. Columns 1, 3, and 5 show the post-separation reductions in calendar year weeks of employment at the average unemployment rate; columns 2, 4, and 6 give the additional impact of a one percentage point increase in unemployment. For example, columns 3 and 4 of row 1 indicate that permanent layoffs involving short tenure workers lead to an employment loss of approximately 13 weeks in "average" years and an additional $2 \frac{1}{2}$ weeks when the sample unemployment rate is one percentage point above average.

\footnotetext{
${ }^{11}$ Weeks of employment, rather than unemployment, are used to compensate for possible inter-group differences in cyclical labor force participation patterns.
} 
Separations are always associated with statistically significant declines in weeks worked. Losses are largest for short tenure workers, ranging from 8 to 13 weeks, as compared to 1 to 8 weeks for those with more seniority. Permanent layoffs lead to the greatest employment reductions, quits to the smallest. Tenure group differences are also present for the recent changers subsample but are less pronounced and typical reductions in post-separation employment are larger.

Cyclical fluctuations in post-separation employment differ sharply for the full sample and for recent job changers. Full sample cyclical effects are small with a $1 \%$ increase in the unemployment rate adding less than 2 weeks of nonemployment for temporary and voluntary separations and 2 to 4 weeks for involuntary layoffs. Tenure group differences are relatively minor and without a clear pattern. Conversely, in the subsample, cyclical changes are more pronounced, with especially large fluctuations among the longest tenure group. For instance, a one percentage point increase in sample unemployment reduces employment among leavers of "long" current jobs by 1 to 4 weeks but by a much greater $3 \frac{1}{2}$ to 16 weeks for individuals experiencing a second separation after having departed a "long" job within the preceding two years.

\section{Simulation Results}

The relative importance of fluctuations in separation probabilities and in post-separation weeks of employment is estimated by calculating the expected percent- age change in each when the unemployment rate rises from 0.75 percentage points below its sample average rate of $2.72 \%$ to 0.75 percentage points above. The resulting hypothetical peak and trough rates of $1.97 \%$ and $3.47 \%$ are similar to the actual sample minimum and maximum of $1.82 \%$ and $3.46 \%$ which occurred in 1973 and 1975 , respectively. ${ }^{12}$

The simulation findings are presented in table 4 and can be summarized as follows. First, variability in post- separation employment explains a greater share of cyclical employment fluctuations than changes in separation probabilities. Second, cyclical variations in both variables increase with current job tenure. For instance, long tenure workers are 11 times more likely to separate

\footnotetext{
${ }^{12}$ Low unemployment rates result from restricting the sample to adult male household heads.
} 
Table 3.- Average and Cyclical Fluctuation of Changes in WeEKS WORKED Following Job SEPARATIONS

\begin{tabular}{|c|c|c|c|c|c|c|}
\hline \multirow{3}{*}{$\begin{array}{l}\text { Tenure } \\
\text { (years) }\end{array}$} & \multicolumn{6}{|c|}{ Type of Separation } \\
\hline & \multicolumn{2}{|c|}{ Temporary } & \multicolumn{2}{|c|}{ Involuntary } & \multicolumn{2}{|c|}{ Voluntary } \\
\hline & $\overline{A V E}$ & $\overline{U R A T E}$ & $A V E$ & $\overline{U R A T E}$ & $A V E$ & URATE \\
\hline \multicolumn{7}{|c|}{ All Workers (Current Tenure) } \\
\hline$<3$ & $\begin{array}{c}-8.72 \\
(-15.03)\end{array}$ & $\begin{array}{c}-1.57 \\
(-1.75)\end{array}$ & $\begin{array}{c}-13.05 \\
(-25.09)\end{array}$ & $\begin{array}{c}-2.62 \\
(-3.12)\end{array}$ & $\begin{array}{c}-8.06 \\
(-17.91)\end{array}$ & $\begin{array}{c}-0.17 \\
(-0.25)\end{array}$ \\
\hline $3-9$ & $\begin{array}{c}-6.33 \\
(-15.44)\end{array}$ & $\begin{array}{c}-1.59 \\
(-2.37)\end{array}$ & $\begin{array}{c}-6.78 \\
(-12.56)\end{array}$ & $\begin{array}{c}-1.96 \\
(-2.20)\end{array}$ & $\begin{array}{c}-2.83 \\
(-6.90)\end{array}$ & $\begin{array}{c}-1.62 \\
(-2.57)\end{array}$ \\
\hline$\geq 10$ & $\begin{array}{c}-6.07 \\
(-14.80)\end{array}$ & $\begin{array}{c}-1.27 \\
(-1.98)\end{array}$ & $\begin{array}{c}-7.68 \\
(-9.37)\end{array}$ & $\begin{array}{c}-3.63 \\
(-2.75)\end{array}$ & $\begin{array}{c}-1.42 \\
(-2.58)\end{array}$ & $\begin{array}{l}-1.91 \\
(-2.22)\end{array}$ \\
\hline \multicolumn{7}{|c|}{ Recent Changers (Prior Tenure) } \\
\hline$<3$ & $\begin{array}{l}-12.01 \\
(-6.90)\end{array}$ & $\begin{array}{c}-2.60 \\
(-1.02)\end{array}$ & $\begin{array}{c}-14.37 \\
(-12.08)\end{array}$ & $\begin{array}{c}-1.96 \\
(-1.05)\end{array}$ & $\begin{array}{c}-12.20 \\
(-11.30)\end{array}$ & $\begin{array}{c}-1.97 \\
(-1.23)\end{array}$ \\
\hline $3-9$ & $\begin{array}{c}-6.51 \\
(-6.51)\end{array}$ & $\begin{array}{c}-2.63 \\
(-1.68)\end{array}$ & $\begin{array}{l}-11.86 \\
(-11.40)\end{array}$ & $\begin{array}{c}-2.35 \\
(-1.36)\end{array}$ & $\begin{array}{c}-5.58 \\
(-5.58)\end{array}$ & $\begin{array}{c}-3.09 \\
(-2.03)\end{array}$ \\
\hline$\geq 10$ & $\begin{array}{c}-10.27 \\
(-6.89) \\
(1)\end{array}$ & $\begin{array}{c}-3.65 \\
(-1.57) \\
(2)\end{array}$ & $\begin{array}{c}-13.11 \\
(-5.56) \\
(3)\end{array}$ & $\begin{array}{c}-16.14 \\
(-3.64) \\
(4)\end{array}$ & $\begin{array}{c}-6.14 \\
(-3.79) \\
(5)\end{array}$ & $\begin{array}{c}-3.80 \\
(-1.58) \\
(6)\end{array}$ \\
\hline
\end{tabular}

Table 4.-Percentage Changes in Annual Separation Probabilities aNd SEPARATION Year EMPLOYMENT REDUCTIONS WHEN THE UNEMPLOYMENT RISES FROM 0.75\% BELOW TO $0.75 \%$ ABOVE ITS AVERAGE RATE

\begin{tabular}{|c|c|c|c|c|}
\hline \multirow[b]{2}{*}{ Tenure (years) } & \multicolumn{2}{|c|}{ All Workers } & \multicolumn{2}{|c|}{ Recent Changers } \\
\hline & $\begin{array}{l}\text { (Currer } \\
\text { Separation } \\
\text { Probability }\end{array}$ & $\begin{array}{l}\text { Tenure) } \\
\text { Reduction in } \\
\text { Employment }\end{array}$ & $\begin{array}{l}\quad \text { (Prior } \\
\text { Separation } \\
\text { Probability }\end{array}$ & $\begin{array}{l}\text { Tenure) } \\
\text { Reduction in } \\
\text { Employment }\end{array}$ \\
\hline$<3$ & $\begin{array}{r}8.0 \% \\
(0.88)\end{array}$ & $\begin{array}{l}23.7 \% \\
(2.66)\end{array}$ & $\begin{array}{l}-10.0 \% \\
(-0.86)\end{array}$ & $\begin{array}{l}30.8 \% \\
(1.76)\end{array}$ \\
\hline $3-9$ & $\begin{array}{c}8.4 \\
(0.79)\end{array}$ & $\begin{array}{l}81.9 \\
(4.55)\end{array}$ & $\begin{array}{l}78.6 \\
(4.88)\end{array}$ & $\begin{array}{l}83.1 \\
(3.01)\end{array}$ \\
\hline$\geq 10$ & $\begin{array}{l}50.5 \\
(3.88)\end{array}$ & $\begin{array}{l}97.8 \\
(4.35)\end{array}$ & $\begin{array}{l}53.0 \\
(2.02)\end{array}$ & $\begin{array}{c}168.0 \\
(3.47)\end{array}$ \\
\hline All & $\begin{array}{l}41.5 \\
(6.10)\end{array}$ & $\begin{array}{l}51.3 \\
(6.18)\end{array}$ & $\begin{array}{l}37.5 \\
(3.95)\end{array}$ & $\begin{array}{l}61.9 \\
(4.21)\end{array}$ \\
\hline
\end{tabular}

Note: $t$-statistics in parentheses

from jobs in hypothetical recession years than peak periods and if they do separate will be out of work twice as long. For short tenure workers, the corresponding cyclical changes are only around $20 \%$. Third, cyclical fluctuations are generally larger for recent job changers than for the full sample. Again the differences increase with tenure with particularly large changes for the most senior category. This verifies evidence in section II, indicating that recent changers of long jobs account for disproportionate shares of cyclical employment fluctuations.

\section{Conclusion}

This paper confirms earlier research showing an in- verse relationship between job duration and turnover rates. Low tenure workers account for a disproportionate share of total unemployment, both because they are more likely to terminate jobs than their more senior counterparts and because separations lead to greater reductions in employment. 
Although responsible for a relatively small share of total unemployment, workers with substantial tenure in recently held jobs constitute a much larger proportion of cyclical fluctuations in employment and unemployment. Persons with short current job tenure who have recently held longer jobs appear unusually vulnerable to deteriorating economic conditions. For most groups, fluctuations in post-separation weeks of employment, rather than changes in separation probabilities, are the primary factor explaining cyclical changes in employment.

This paper's results are qualified by limitations in the sample and time period examined, nonetheless, several tentative conclusions emerge. Although low tenure male heads of households may well by "stuck" in inherently unstable jobs, there is little evidence that this instability is especially acute during economic downturns. Instead, recent leavers of longer jobs become relatively more vulnerable in recessions. Traditionally, the welfare losses of these workers have been minimized by unemployment compensation-including extended benefits during periods of high unemployment. Recent changes in eligibility standards have eliminated much of this protection. For example, Burtless (1983) has shown that less than half of unemployed workers received benefits during the 1982 recession. To the extent that a major burden of economic downturns rests upon persons recently departing "long" jobs, extended unemployment benefits and targeted retraining programs may be justified to mitigate these losses. ${ }^{13}$ Before redesigning existing programs, a sounder theoretical basis is required.

One interesting possibility is suggested by recent work considering the role of recessions in redistributing labor across sectors of the economy. ${ }^{14}$ Since high tenure workers are relatively immune from transitory demand shocks, we might expect short tenure workers to bear the brunt of temporary fluctuations in demand. Large scale cutbacks and plant closures occurring during recessions would then impact workers higher up on seniority ladders, increasing their share of unemployment. This effect will be strengthened if recessions are "unbalanced," hitting declining sectors especially hard. Persons leaving high tenure jobs in good economic periods would be vulnerable to subsequent separations during recessions, if employment had been obtained in declining industries. Subsequent job displacement would then result in significant unemployment as work in the declining sector becomes increasingly scarce.

\section{REFERENCES}

Abraham, Katharine G., and Lawrence F. Katz, Cyclical Un-employment: Sectoral Shifts or Aggregate Disturbances, Working Paper \#1410, National Bureau of Economic Research, July 1984.

Akerlof, George A., and Brian G. M. Main, "Unemployment Spells and Unemployment Experience," American Economic Review 70 (Dec. 1980), 885-893.

Burtless, Gary, "Why Is the Insured Unemployment Rate So Low?" Brookings Papers on Economic Activity (1, 1983), 225-253.

Clark, Kim B., and Lawrence H. Summers, "Labor Market Dynamics and Unemployment: A Reconsideration," Brookings Papers on Economic Activity (1, 1979), 13-72.

, "Demographic Differences in Cyclical Employment Variations," Journal of Human Resources 16 (Winter 1981), 61-79.

\footnotetext{
13 The Trade Adjustment Assistance Program is one example.

${ }^{14}$ See Lilien (1982) for one such model and Abraham and Katz (1984) for critiques.
} 
Darby, Michael, John Haltiwanger, and Mark Plant, "Un- employment Rate Dynamics and Persistent Unemployment Under Rational Expectations," American Eco-nomic Review 75 (Sept. 1985), 614-637.

Feldstein, Martin S., Lowering the Permanent Rate of Unemployment (Washington, D.C.: Joint Economic Commit- tee, U.S. Congress, U.S. Government Printing Office, 1973).

Hall, Robert E., "Turnover in the Labor Force," Brookings Papers on Economic Activity (1972), 709-756.

Lilien, David M., "Sectoral Shifts and Cyclical Unemployment," Journal of Political Economy 90 (Aug. 1982), 777-793.

Lucas, Robert E, and Leonard A. Rapping, "Real Wages, Employment, and Inflation," Journal of Political Economy 77 (Sept.-Oct. 1969), 721-754.

MaCurdy, T. E., "An Empirical Model of Labor Supply in A Lifecycle Setting," Journal of Political Economy 89 (Dec. 1981), 1059-1085.

Marston, Stephen T., "Employment Instability and High Turnover Rates," Brookings Papers on Economic Activity (1, 1976), 169-203.

Piore, Michael J. (ed.), Unemployment and Inflation: Institutional and Structuralist Views (White Plains, NY: M. E Sharpe, 1979).

Raisian, John, "Contracts, Job Experience, and Cyclical Labor Market Adjustments," Journal of Labor Economics 1 (Apr. 1983), 152-170.

Ruhm, Christopher J., "Heterogeneous Workers, Wages, and Labor Mobility," mimeo, Boston University (June 1986). 